\title{
Research on the Teaching of College Mathematics
}

\author{
Xu Zhenming \\ School of Information Science \& Technology \\ Xiamen University Tan Kah Kee College \\ Zhangzhou, Fujian, China \\ xzm@xujc.com
}

\begin{abstract}
With the continuous development of education informatization, teaching should be continuously improved. This paper first elaborates the use of "flip classroom" to improve the teaching of college mathematics and its advantages and precautions, and then based on the "Cone of Learning" principle, put forward some measure to further improve the quality of college mathematics teaching. After a period of teaching practice, they get very good results, and we will continue to study and improve the teaching of college mathematics.
\end{abstract}

Keywords-Teaching Model; College Mathematics; "flip classroom"; Teach Others

\section{INTRODUCTION}

Today, wisdom education leads the development of education informatization. Over the years, there are many researches on the concept, architecture, development path, environment construction and application practice of wisdom education [1]. There are many teaching models based on the wisdom of education, one of the most popular is "flip classroom".

College mathematics includes "Advanced Mathematics", "Linear Algebra" and "Probability Theory and Mathematical Statistics". As basic compulsory courses for institutions of higher learning, college mathematics has the characteristics of "teachers are difficult to teach", "students are difficult to learn", "failure rate is high" and so on [2]. It is urgent to reform the university mathematics teaching so as to improve the teaching efficiency and the students' learning effect.

Thus, this paper attempts to apply the "flip classroom" to the teaching of college mathematics. And pointed out some of the considerations in the application process, according to some of the characteristics of college mathematics. Finally, according to the "Cone of Learning", this paper pointed out how to further improve the learning effect of college mathematics on the basis of the "flip classroom".

\section{THE APPLICATION OF “FLIP CLASSROOM” IN COLLEGE MATHEMATICS TEACHING}

Over the years, as the most popular teaching mode of wisdom education, "flip classroom" has been repeatedly studied and widely applied to the teaching of various disciplines. The general process of "flip classroom" [3]:

(1) The teacher records the video to explain a new knowledge point of college mathematics, and then upload and release to students through the network or some smartphone application.

(2) The students download and learn this video within the specified time.

(3) The teacher organizes a discussion about the learning of this video, and the students participate in discussions with questions in pre-learning of this video.

(4) The teacher summarizes the questions in the discussion and feeds them back to the students.

The teaching model of "flip classroom" has a series of advantages, including:

(1) Change the order of teaching and learning[4][5]. The students learn a new knowledge point through video that recorded by teacher, and then participate in the discussion or lecture with questions. So that the students know what to understand and then listen carefully. The effect of the lectures is certainly better.

(2) The students can learn more freedom and efficiency. The students can choose their learning time according to their own state, to ensure the best learning effect, and will not missed the teacher's explain because of drowsily in the traditional classroom.

(3) The video can be viewed repeatedly, to solve the problem of easy to forget what the teacher taught in the classroom.

When applying the teaching model of "flip classroom" to the teaching of college mathematics, it should be noted that:

(1) Mathematical knowledge is always boring, the teaching video recorded can not be vivid and interesting. It is difficult to attract students to complete their own teaching video learning. Therefore, it must have a corresponding mechanism to ensure that students complete the video learning within the specified time. For example, use IT technology to ensure and record that students watch the video in the phone or computer with a registered account.; Design exercises and ask students to complete the exercises before the discussion, to ensure that students must learn the contents of the video, and so on. At the appropriate time, use email or phone short messages to remind students who have not completed yet.

(2) The content of college mathematics is special, it has more formulas, and difficult to edit (cumbersome, slow). It is more difficult for students to complete online testing. The 
teacher should try to use multiple choice questions when designing test questions, and the interactive software that teaching used should support formula editing and must be easy to edit.

(3) There are a large number of students who study college mathematics, the class size is relatively large. There are many difficulties in the organization of the discussions and in the coordination of different classes. Therefore, the management and support at the school level have an indispensable effect on the smooth implementation of the "flip classroom".

After a period of actual operation, although teachers have increased the workload of recording video and summary of questions, but the teaching effect is still significantly improved; Students have also added a great deal of extra-curricular learning time, but the learning initiative and effect of student improved significantly too; the course examination results have made great progress.

\section{TO FURTHER IMPROVE THE LEARNING EFFECT OF COLLEGE MATHEMATICS}

According to the "Cone of Learning" ( Fig. 1 ) theory putted forward by American scholar Edgar Dale in 1946, "Lecture" is the most familiar and most commonly used learning method which located in the pyramid spire, the content that had learned with this method left five percent after two weeks. The vast majority of college mathematics teaching still use this method, and the teaching effect can be imagined.

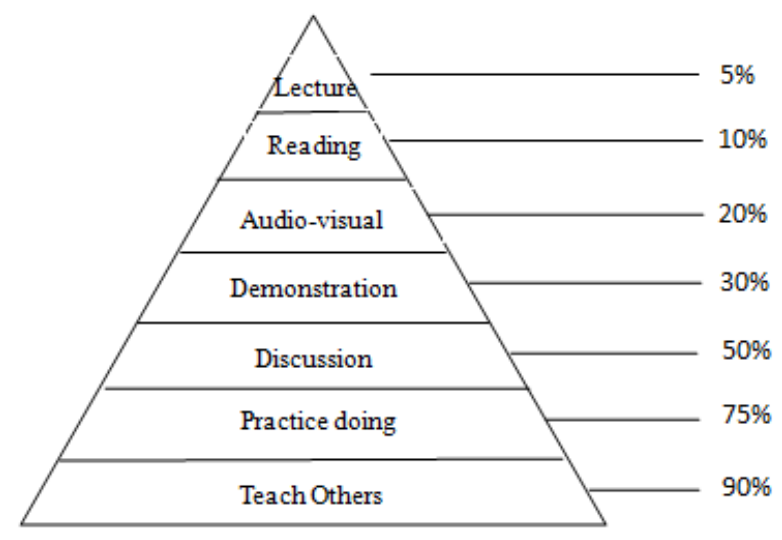

Fig. 1 Cone of Learning

And the learning method that located in the third floor (updown) of the pyramid is "Audio-visual", the content that had learned by listening the audio or watching the video left twenty percent after two weeks. The learning method that located in the fifth floor (up-down) of the pyramid is "Discussion", the content that had learned with discussion left fifty percent after two weeks. Thus, "flip classroom" that use of these two methods improved the learning effect significantly.

But twenty percent, even fifty percent is clearly not our goal. In the "Cone of Learning" theory, the learning method at the bottom of the pyramid is "Teach Others". The same percentage of this method is increased to ninety percent. This is an ideal learning method because of the high proportion.

According to this theory, we should try to find ways to let students use the knowledge that have learned to teach others, in the teaching that based on "flip classroom" of college mathematics, to achieve a better learning effect.

For example, we should allow students to ask questions encountered in learning, by smartphone application or web page, while others can see. When someone sees the problem and can solve it, he can contact the person who raised the question and help it solve the problem. After the question is solved, the person asking the question will have feedback on the smartphone application or web page, and the smartphone application or web page will register the problem-solving person.

We can make a list in mobile phone application or web page, showing the number of times to help others solve the problem, and give some incentives in the course of assessment based on the list, to improve the enthusiasm of students to teach others.

There is more communication between students through discussion in "flip classroom" and implementation of "Teach others". As learning effects improve, friendship between students also gets better.

\section{CONCLUSIONS}

This paper explains how to use "flip classroom" to improve the teaching effect of college mathematics and to further improve the teaching effect of college mathematics according to the principle of "Cone of Learning" , under the background of education informationization led by wisdom education.

However, teaching is a dynamic process. With the continuous development of society and the continuous reform of education, especially the further development of education informationization led by wisdom education, Teaching of all courses (including college mathematics) must be continually reformed. More new teaching methods and teaching mode will appear, and more modern technology will also be used in teaching. Therefore, we must maintain the vitality of teaching through constant study and follow-up.

\section{REFERENCES}

[1] Guo Hongxia, Research Summary of Smart Education in China. from 2005 to 2015, Journal of Digital Education, 2016(1):16-21.

[2] Teaching Guidance Subcommittee of College Mathematics Teaching in High School, The Present Situation of College Mathematics Teaching and Suggestions on Improving Teaching Quality. Journal of China University Teaching. 2005(2): 9-11.

[3] Yan Lanlan, Liu Shenglan,To Improve The Quality of College Mathematics Teaching with the Help of Flipped Classrom, Journal of East China University of Technology(Social Science). 2016,35(1):89-92.

[4] Zhu Zhiting, New Developments of Smarter Education: From Flipped Classroom to Smart Classroom and Smart Learning Space. Journal of Open Education Research, 2016,22(1):18-26.

[5] Dai Hongbin, Flip Classroom Teaching Process and Interactive System Design Based on Wisdom Teaching Concept, Journal of ICT in Education,2016(22):29-3. 